\title{
PENGARUH RELIGIUSITAS, KESADARAN WAJIB PAJAK DAN PENGETAHUAN PERPAJAKAN TERHADAP KEPATUHAN WAJIB PAJAK
}

\author{
Nanik Ermawati \\ Jurusan Akuntansi Universitas Muria Kudus
}

\begin{abstract}
This reseach aims to determine how the influence between religiosity, taxpayer awareness and knowledge taxation on taxpayer compliance for individual taxpayers at the Tax Office Pratama Pati. Methods of data collection by distributing questionnaires to individual taxpayers. The sample used is accidental sampling method. Data analysis techniques using multiple regression techniques. The results showed that: 1). Religiosity affects taxpayer compliance, 2). Awareness of taxpayers affect taxpayer compliance and 3). Knowledge of taxation does not affect taxpayer compliance.
\end{abstract}

Keywords: religiosity, taxpayer awareness, taxpayer compliance, knowledge taxation.

\begin{abstract}
ABSTRAK
Penelitian ini bertujuan untuk mengetahui bagaimana pengaruh antara religiusitas, kesadaran wajib pajak dan pengetahuan perpajakan terhadap kepatuhan wajib pajak bagi wajib pajak orang pribadi pada Kantor Pelayanan Pajak Pratama Kabupaten Pati. Metode pengumpulan data dengan menyebarkan kuesioner kepada wajib pajak orang pribadi. Sampel yang digunakan menggunakan metode accidental sampling. Teknik analisis data menggunakan teknik regresi berganda. Hasil penelitian menunjukkan bahwa : 1). Religiusitas berpengaruh terhadap kepatuhan wajib pajak, 2). Kesadaran wajib pajak berpengaruh terhadap kepatuhan wajib pajak dan 3). Pengetahuan perpajakan tidak berpengaruh terhadap kepatuhan wajib pajak.
\end{abstract}

Kata Kunci : Religiusitas, kesadaran wajib pajak, kepatuhan wajib pajak, pengetahuan perpajakan.

\section{PENDAHULUAN}

Pajak merupakan sumber utama pendapatan negara di Indonesia. Pendapatan negara ini akan digunakan pemerintah untuk menjalankan perekonomian Negara. Begitu pentingnya peran pajak bagi negara, maka pemerintah berupaya terus untuk meningkatkan jumlah pajak yang di setorkan ke kas negara. Upaya pemerintah untuk meningkatkan jumlah pajak dilakukan dengan segala cara supaya wajib pajak membayar pajak tepat waktu dan tanpa merasa dipaksa. Upaya pemerintah ini akan meningkatkan tingkat kepatuhan wajib pajak dalam menjalankan kewajiban perpajakan. Menurut Widagsono (2017), kepatuhan wajib pajak adalah sikap yang dimiliki wajib pajak dalam menjalankan kewajiban perpajakan sesuai 
dengan peraturan perpajakan, dimana wajib pajak diwajibkan untuk membayar pajak dan diwajibkan untuk melaporkan Surat Pemberitahuan (SPT).

Sikap wajib pajak dalam menjalankan kewajiban perpajakan dipengaruhi oleh beberapa faktor. Berdasarkan penelitian yang telah dilakukan oleh Retyowati (2016), Anggraeni (2016) menunjukkan bahwa kepatuhan wajib pajak dipengaruhi oleh religiusitas. Religiusitas merupakan keyakinan yang dimiliki oleh wajib pajak bahwa wajib pajak percaya terhadap Tuhan, dimana wajib pajak takut melakukan pelanggaran peraturan pajak (Basri, 2015). Melakukan pelanggaran peraturan perpajakan merupakan perilaku yang tidak etis, karena merugikan Negara. Perilaku tidak etis inilah yang merupakan dimensi dari religiusitas. Namun penelitian yang dilakukan oleh Tania (2011) memberikan bukti yang berbeda dimana religiusitas tidak dapat berpengaruh terhadap kepatuhan wajib pajak.

Selain religiusitas, menurut Anggraeni (2016), Effendi dan Aris (2016) kepatuhan wajib pajak juga dipengaruhi oleh kesadaran wajib pajak. Kesadaran wajib pajak merupakan kondisi dimana wajib pajak mampu untuk mengetahui tentang peran pajak begitu pentingnya bagi Negara sehingga wajib pajak secara tulus menjalankan kewajiban perpajakannya (Effendi dan Aris, 2016). Bagi wajib pajak yang sadar akan begitu pentingnya peran pajak, maka wajib pajak akan semakin mematuhi peraturan pajak. Namun penelitian yang dilakukan oleh (Tahar dan Rachman, 2014) menunjukkan bukti bahwa kesadaran wajib pajak tidak dapat berpengaruh terhadap kepatuhan wajib pajak.

Faktor lain yang mempengaruhi kepatuhan wajib pajak menurut Widagsono (2017) yaitu pengetahuan perpajakan. Pengetahuan perpajakan merupakan ilmu yang dimiliki oleh wajib pajak mengenai tata cara perpajakan bagaimana cara menghitung pajak, bagaimana cara membayar pajak dan bagaimana cara melaporkan pajak. Ilmu yang dimiliki wajib pajak akan mempengaruhi seberapa jauh wajib pajak mematuhi peraturan perpajakan. Namun penelitian yang pernah dilakukan oleh Rahmawaty (2014) menunjukkan hasil bahwa pengetahuan perpajakan tidak dapat berpengaruh terhadap kepatuhan wajib pajak.

Berdasarkan riset gap yang telah di kemukan di atas, maka peneliti tertarik untuk meneliti lebih lanjut tentang faktor yang berpengaruh terhadap kepatuhan wajib pajak. Penelitian ini mengacu pada penelitian yang telah dilakukan oleh Widagsono (2017). Perbedaan penelitian ini dengan Widagsono (2017) adalah dengan menambah variabel independen yaitu kesadaran wajib pajak. Oleh karena itu maka peneliti termotivasi untuk melakukan penelitian yang berjudul "Pengaruh Religiusitas, Kesadaran Wajib Pajak dan Pengetahuan Perpajakan terhadap Kepatuhan Wajib Pajak". 


\section{Masalah Penelitian}

Rumusan masalah yang diajukan dalam penelitian ini sebagai berikut : 1). Apakah religiusitas berpengaruh terhadap kepatuhan wajib pajak 2). Apakah kesadaran wajib pajak berpengaruh terhadap kepatuhan wajib pajak 3). Apakah pengetahuan perpajakan berpengaruh terhadap kepatuhan wajib pajak. Adapun tujuan dari penelitian ini adalah untuk mengetahui pengaruh religiusitas, kesadaran wajib pajak dan pengetahuan perpajakan berpengaruh terhadap kepatuhan wajib pajak.

\section{Kajian Teoritis}

\section{Theory Plan Behaviour (TPB)}

Theory of Planned Behaviour menurut Khasanah (2014) adalah teori yang menyatakan bahwa seseorang akan melakukan suatu perbuatan yang baik jika ada suatu motivasi yang mendorong untuk bertindak. Seseorang yang dimaksudkan disini adalah wajib pajak. Wajib pajak dalam menjalankan kewajiban perpajakan dimotivasi oleh beberapa faktor. Faktor motivasi inilah yang menyebabkan wajib pajak berusaha untuk mematuhi peraturan pajak. Wajib pajak berusaha untuk membayar pajak sesuai dengan kondisi perusahaan. Dalam membayar pajak tersebut wajib pajak tidak akan merasa berat hati karena wajib pajak termotivasi ketika membayar pajak tepat waktu akan meningkatkan penerimaan Negara. Kesadaran wajib pajak inilah yang menyebabkan wajib pajak patuh terhadap peraturan pajak.

\section{Kepatuhan Wajib Pajak}

Kepatuhan wajib pajak menurut Widagsono (2017) adalah sikap wajib pajak dalam mematuhi Undang-Undang Pajak. Sedangkan menurut Rahmawaty (2014) kepatuhan wajib pajak merupakan kemauan wajib pajak membayar pajak secara ikhlas. Dapat disimpulkan bahwa kepatuhan pajak merupakan sikap wajib pajak yang secara rela dan ikhlas tanpa dipaksa untuk menjalankan kewajiban perpajakan yang berupa menghitung pajak, membayar pajak sendiri dan melaporkan pajak. Disini wajib pajak rela menghitung pajak yang akan dibayar tanpa merasa di paksa.

\section{Religiusitas}

Religiusitas merupakan sikap etis wajib pajak dimana wajib pajak mempercayai adanya Tuhan (Basri, 2015). Menurut Capanna, et al, (2013) religiusitas adalah seseorang yang meyakini terhadap agama tertentu dimana seseorang tersebut menjalankan perintah agama dan menjauhi larangan agama. Seseorang yang dimaksud disini adalah wajib pajak. Wajib pajak yang lebih dekat dengan agama, maka wajib pajak akan berusaha menjalankan 
perintah agama. Wajib pajak menganggap jika melanggar peraturan agama maka wajib pajak akan merasa berdosa. Wajib pajak disini takut untuk melakukan hal yang tidak etis yaitu takut untuk tidak mematuhi peraturan perpajakan. Dengan dasar tersebut wajib pajak akan berusaha patuh terhadap peraturan pajak, karena wajib pajak menganggap dengan membayar pajak merupakan perilaku yang etis. Dimana wajib pajak yang memiliki perilaku etis sama saja dengan menjalankan perintah agama. Hasil penelitian Utama dan Wahyudi (2016), Benk, et al (2016), Retyowati (2016), Anggraeni (2016), Torgler (2012), Wati (2016)menunjukkan hasil bahwa wajib pajak yang memiliki religiusitas tinggi, maka wajib pajak tersebut akan berusaha patuh terhadap peraturan perpajakan. Berdasarkan uraian di atas dapat ditarik hipotesis sebagai berikut :

\section{$H 1$ : religiusitas berpengaruh terhadap kepatuhan wajib pajak}

\section{Kesadaran Wajib Pajak}

Kesadaran wajib pajak merupakan kondisi wajib pajak, dimana wajib pajak secara sadar penuh bahwa membayar pajak secara tepat waktu dan sukarela merupakan kewajiban wajib pajak (Suhartini, 2012). Sedangkan menurut Utami, et al (2011) kesadaran wajib pajak adalah sikap wajib pajak bagaimana seharusnya wajib pajak bertindak sesuai dengan perpaturan pajak tanpa ada paksaan. Jadi dapat disimpulkan kesadaran wajib pajak merupakan sikap wajib dalam dalam menjalankan kewajiban perpajakannya tidak ada paksaan dengan kesadarannya sendiri bahwa membayar pajak merupakan kewajiban. Wajib pajak menganggap bahwa membayar pajak adalah kewajiban bagi warga negara Indonesia dalam rangka membangun Negara. Dengan kata lain, wajib pajak yang memahami benar peran pajak bagi perekonomian Negara akan berusaha mematuhi pajak dengan membayar pajak tepat waktu. Sikap wajib pajak ini lah yang meningkatkan tingkat kepatuhan wajib pajak. Dengan membayar pajak tepat waktu, maka pembangunan Negara akan menjadi lebih berkembang. Hal ini sejalan dengan penelitian yang telah dilakukan oleh Utami, et al (2011), Arum (2012), Jotopurnomo, et al (2013), yang menunjukkan hasil bahwa semakin tinggi kesadaran yang dimiliki wajib pajak tentang peran penting dari pajak, maka wajib pajak akan semakin mematuhi peraturan perpajakan. Berdasarkan uraian di atas, maka dapat dibuat hipotesis sebagai berikut :

\section{H2 : kesadaran wajib pajak berpengaruh terhadap kepatuhan wajib pajak}

\section{Pengetahuan Perpajakan}

Pengetahuan perpajakan merupakan informasi yang dimiliki wajib pajak mengenai hal-hal yang berkaitan dengan tata cara perpajakan (Wati, 2016). Sedangkan menurut Widayati dan Nurlis (2010) mengemukakan tentang pengetahuan perpajakan yaitu ilmu yang 
dimiliki wajib pajak mengenai pajak sehingga wajib pajak memahami bagaimana hal-hal yang menyangkut tentang kewajiban pajak. Hal ini dapat disimpulkan bahwa pengetahuan perpajakan adalah seberapa banyakkah ilmu yang dimiliki oleh wajib pajak, ketika wajib pajak menjalankan kewajiban perpajakan. Bagi wajib pajak yang paham betul tentang kewajiban perpajakan, maka wajib pajak berusaha untuk mematuhi peraturan perpajakan. Wajib pajak akan membayar pajak tepat waktu dan melaporkan pajaknya secara tepat waktu. Hasil penelitian yang pernah dilakukan oleh Widagsono (2017), Rahmawaty (2014), Wati (2016) menemukan bukti bahwa wajib pajak yang memiliki pengetahuan yang banyak tentang aturan perpajakan, maka akan meningkatkan tingkat kepatuhan wajib pajak dalam menjalankan kewajiban perpajakannya. Berdasarkan uraian di atas, maka dapat dihipotesiskan sebagai berikut :

\section{H3 : pengetahuan perpajakan berpengaruh terhadap kepatuhan waajib pajak}

Berdasarkan hipotesis yang diajukan dalam model penelitian di atas, maka dapat dibuat gambar kerangka pemikiran hipotesis sebagai berikut :

\section{Gambar 1}

\section{Kerangka Pemikiran Hipotesis}

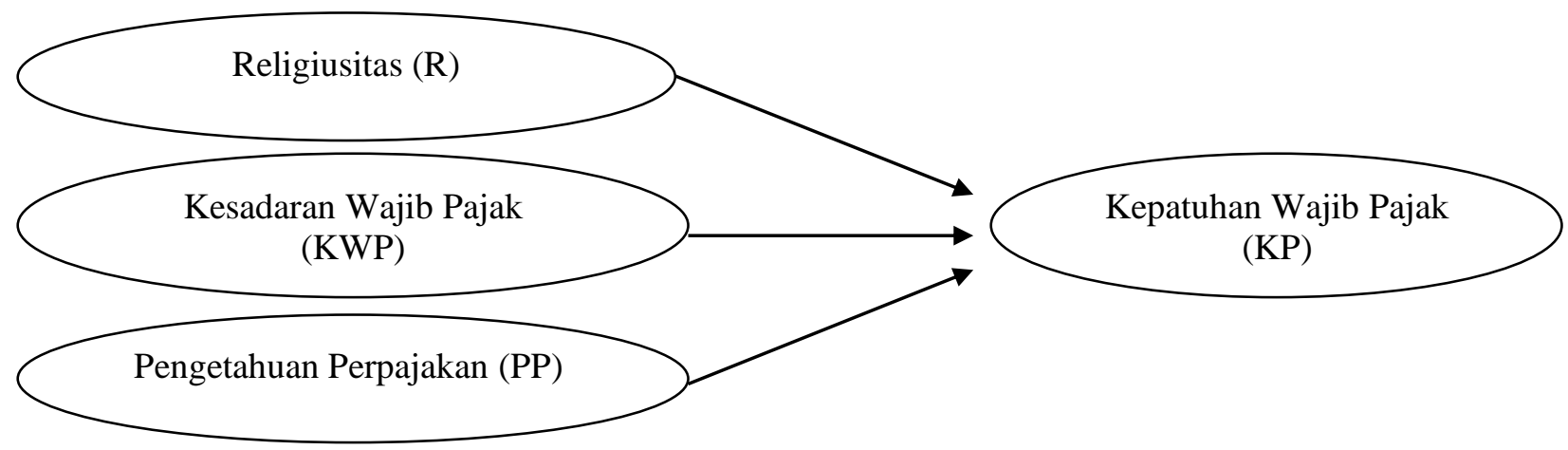

Sumber : Diolah Penulis, 2018

\section{Metodologi}

\section{Jenis Data dan Sumber Data}

Jenis data yang digunakan dalam penelitian ini adalah jenis data kuantitatif. Data kuantitatif adalah data yang yang dapat diukur dan dihitung secara langsung (Sugiyono, 2010). Sumber data yang digunakan dalam penelitian ini adalah sumber data primer. Sumber data primer adalah data yang pertama kali dicatat dan dikumpulkan oleh peneliti (Sanusi, 2017).

\section{Populasi dan Sampel Penelitian}

Populasi yang digunakan dalam penelitian ini adalah wajib pajak orang pribadi yang terdaftar pada Kantor Pajak Pratama Kabupaten Pati. Teknik pengambilan sampel dalam penelitian ini 
adalah metode Accidental Sampling. Accidental Sampling adalah teknik pengambilan sampel dengan cara memberikan kuesioner kepada responden yang dijumpai pada saat itu dengan alasan mempermudah dalam memperoleh sampel. Untuk menentukan jumlah sampel penelitian, maka peneliti menggunakan teori Kuncoro dan Sudarman (2018) yang menjelaskan bahwa penentuan jumlah sampel untuk penelitian multivariate (regresi) peneliti mengambil 100 orang responden.

\section{Definisi Operasional Variabel}

Variabel dalam penelitian terdiri dari variabel dependen dan variabel independen. Variabel dependen terdiri dari kepatuhan wajib pajak, sedangkan variabel independen terdiri dari religiusitas, kesadaran wajib pajak dan pengetahuan perpajakan. Berikut ini pengertian dari variabel yang digunakan dalam penelitian sebagai berikut :

a. Religiusitas : Tindakan manusia dalam mempercayai agama masing-masing dengan tata cara sesuai dengan kepercayaan masing-masing (Capanna, et al, 2013). Instrumen yang digunakan menggunakan instrumen yang telah dilakukan oleh Ancok dan Suroso (2011) dengan memakai lima dimensi diantaranya : keyakinan, praktek agama, penghayatan, pengetahuan agama, pengalaman.

b. Kesadaran Wajib Pajak : Sikap wajib pajak dalam mengetahui dan memahami peraturan perpajakan secara ikhlas (Anggraeni, 2016). Instrumen yang digunakan menggunakan instrumen yang telah dilakukan oleh Anggraeni (2016) dengan 5 item pertanyaan.

c. Pengetahuan Perpajakan : Seberapa jauh ilmu yang dimiliki wajib pajak mengenai pengertian, fungsi, jenis pajak sampai dengan menghitung tarif pajaknya sendiri. Instrumen yang digunakan menggunakan instrumen yang telah dilakukan oleh Fikriningrum (2012).

d. Kepatuhan Wajib Pajak : Kondisi wajib pajak dimana wajib pajak bersedia memenuhi kewajiban pajak sesuai dengan ketentuan dan peraturan dari perpajakan dimana wajib pajak tidak harus melalui tahap pemeriksaan ataupun peringatan dari kantor pajak Widagsono (2017). Instrumen yang digunakan menggunakan instrumen yang telah dilakukan oleh Togler (2012).

\section{Teknik Analisis}

a. Uji Instrumen

Uji instrumen merupakan uji sebuah konstruk penelitian yang terdiri dari dimensi dan indikator (Sanusi, 2017). Uji instrumen terdiri dari uji validitas instrumen dan reliabilitas 
instrumen. Validitas instrumen merupakan tingkat akurasi dan konsistensi instrumen yang digunakan dalam penelitian. Instrumen yang baik adalah instrumen yang valid dengan nilai signifikansi < 0,05 (Ghozali, 2011). Sedangkan uji reliabilitas instrumen merupakan konsistensi hasil pengukuran yang digunakan oleh instrumen penelitian oleh orang yang sama dalam waktu yang berlainan atau di digunakan dalam waktu yang bersamaan dengan orang yang berbeda (Sanusi, 2017). Instrumen yang baik jika memenuhi nilai Cronbach Alpha > 0,60 (Ghozali, 2011).

b. Uji Asumsi Klasik

Uji asumsi klasik harus terpenuhi sebelum menggunakan uji Regresi. Adapun uji asumsi klasik ini terdiri dari : Uji Normalitas, Uji Multikolonieritas, Uji Heteroskedastisitas. Uji Normalitas digunakan untuk melihat data terdistribusi secara normal atau tidak. Model regresi yang baik harus memenuhi uji normalitas. Data dikatakan normal jika memenuhi nilai Kolmogorof Smirnov > 0,5 (Ghozali, 2011). Uji Multikolonieritas digunakan untuk melihat apakah variabel independen satu dengan variabel independen yang lain saling berhubungan. Model regresi yang baik harus terbebas dari Multikolonieritas. Data terbebas dari Multikolonieritas jika memiliki nilai $\mathrm{VIF}<10$, nilai tolerance $>0,1$ (Ghozali, 2011). Uji Heteroskedastisitas digunakan untuk melihat apakah data yang digunakan adalah data yang seragam. Model regresi yang baik adalah yang terbebas dari Heteroskedastisitas. Terbebas dari Heteroskedastisitas dapat dilihat dengan uji Glejser, dimana nilai signifikansi > 0,05 (Sanusi, 2017).

5. Uji Hipotesis

Uji hipotesis yang digunakan adalah Analisis Regresi Linier Berganda. Berikut ini persamaan matematika untuk penelitian ini sebagai berikut :

$$
\mathrm{Y}=\mathrm{a}+b_{1} x_{1}+b_{2} x_{2}+b_{3} x_{3}+\mathrm{e}
$$

Keterangan :

$$
\begin{array}{ll}
\mathrm{Y} & =\text { Kepatuhan Wajib Pajak } \\
x_{1} & =\text { Religiusitas } \\
x_{2} & =\text { Kesadaran Wajib Pajak } \\
x_{3} & =\text { Pengetahuan Perpajakan } \\
b_{1}, b_{2}, b_{3} & =\text { Koefisien Regresi } \\
e & =\text { Variabel Pengganggu }
\end{array}
$$


6. Uji Signifikansi Koefisien Regresi secara Parsial (Uji t)

Uji parsial digunakan untuk menguji hipotesis penelitian untuk mengetahui apakah masing-masing variabel independen baik religiusitas, kesadaran wajib pajak dan pengetahuan perpajakan berpengaruh secara signifikan terhadap kepatuhan wajib pajak. Nilai yang digunakan untuk uji parsial ini adalah jika nilai signifikansi $<0,05$, maka hipotesis penelitian dapat diterima (Ghozali, 2011).

7. Uji Signifikansi Koefisien Regresi secara Simultan (Uji f)

Uji simultan juga merupakan uji model. Uji ini digunakan untuk mengetahui apakah variabel religiusitas, kesadaran wajib pajak dan pengetahuan perpajakan berpengaruh secara bersama-sama terhadap kepatuhan wajib pajak. Nilai yang digunakan untuk uji simultan ini, jika nilai signifikansi $<0,05$, maka hipotesis penelitian diterima (Ghozali, 2011).

7. Koefisien Determinasi $\left(R^{2}\right)$

Koefisien Determinasi merupakan prosentase dari variasi total dalam variabel dependen (Y) yaitu kepatuhan wajib pajak yang hanya dijelaskan oleh variabel independen oleh religiusitas, kesadaran wajib pajak dan pengetahuan perpajakan.

\section{Pembahasan}

1. Uji Instrumen

Hasil uji instrumen ini terdiri dari hasil uji validitas instrumen dan hasil uji reliabilitas instrumen. Berikut ini hasil uji validitas instrumen :

Tabel 1

Hasil Uji Validitas Instrumen

\begin{tabular}{ccc}
\hline Variabel & Indikator & Signifikansi \\
\hline Religiusitas (R) & R1 & 0,00 \\
& R2 & 0,00 \\
& R3 & 0,00 \\
R4 & 0,00 \\
& R5 & 0,00 \\
Kesadaran Wajib Pajak (KWP) & R6 & 0,00 \\
& KWP 1 & 0,00 \\
& KWP 2 & 0,00 \\
& KWP 3 & 0,00 \\
Pengetahuan Perpajakan (PP) & KWP 4 & 0,00 \\
& KWP 5 & 0,00 \\
& PP1 & 0,00 \\
& PP2 & 0,00 \\
& PP3 & 0,00 \\
\hline
\end{tabular}




\begin{tabular}{lll}
\hline & PP4 & 0,00 \\
KP5 & 0,00 \\
PP6 & 0,00 \\
KP 1 & 0,00 \\
KP 2 & 0,00 \\
KP 3 & 0,00 \\
KP 4 & 0,00 \\
KP 5 & 0,00 \\
KP 6 & 0,00 \\
KP 7 & 0,00 \\
\hline
\end{tabular}

Sumber : Diolah Penulis, 2018

Berdasarkan tabel 1 di atas dapat disimpulkan bahwa nilai signifikansi masing-masing variabel sebesar 0,00, hal ini menunjukkan bahwa instrumen penelitian memenuhi uji validitas. Sedangkan hasil uji reliabilitas instrumen dapat di tunjukkan melalui tabel 2 dibawah ini :

Tabel 2

Hasil Uji Reliabilitas Instrumen

\begin{tabular}{|l|c|c|}
\hline \multicolumn{1}{|c|}{ Variabel } & Nilai Cronbach Alpha & Keterangan \\
\hline Religiusitas (R) & 0,669 & $0,669>0,60$ \\
\hline Kesadaran Wajib Pajak (KWP) & 0,845 & $0,845>0,60$ \\
\hline Pengetahuan Perpajakan (PP) & 0,731 & $0,731>0,60$ \\
\hline Kepatuhan Wajib Pajak (KP) & 0,787 & $0,787>0,60$ \\
\hline
\end{tabular}

Sumber : Diolah Penulis, 2018

Berdasarkan tabel 2 di atas di dapatkan nilai Cronbach Alpha menunjukkan nilai yang lebih besar dari 0,60, hal ini menunjukkan bahwa instrumen memenuhi reliabilitas.

\section{Uji Asumsi Klasik}

Hasil uji asumsi klasik terdiri dari : uji normalitas, uji multikolonieritas dan uji heteroskedastisitas. Uji normalitas diuji dengan Kolmogorof Smirnov. Berikut ini menunjukkan hasil uji Kolmogorof Smirnov : 
Tabel 3

Hasil Uji Kolmogorof Smirnov

\begin{tabular}{|c|c|r|}
\hline \multicolumn{2}{|c|}{$N$} & \multicolumn{2}{c|}{ Absolute } \\
\hline \multicolumn{2}{|c|}{$N$} & 100 \\
\hline Normal Parameters $^{a}$ & Mean & $2,92762 \mathrm{E} 3$ \\
\cline { 2 - 3 } & Std. Deviation & 0,055 \\
\hline \multirow{2}{*}{$\begin{array}{c}\text { Most Extreme } \\
\text { Differences }\end{array}$} & Absolute & 0,055 \\
\cline { 2 - 3 } & Positive & $-0,043$ \\
\cline { 2 - 3 } & Negative & $\mathbf{0 , 5 5 1}$ \\
\hline \multicolumn{2}{|c|}{ Kolmogorov-Smirnov Z } & $\mathbf{0 , 9 2 2}$ \\
\hline \multicolumn{2}{|c|}{ Asymp. Sig. (2-tailed) } \\
\hline \multicolumn{2}{|c|}{ a. Test distribution is Normal. } \\
\hline
\end{tabular}

Sumber : Diolah Penulis, 2018

Berdasarkan tabel 3 di atas di dapatkan nilai Kolmogorof Smirnov dengan nilai sebesar 0,551 dan nilai signifikansi sebesar 0,922, hal ini menunjukkan bahwa nilai signifikansinya > 0,5. Dengan kata lain model regresi ini memenuhi kaidah normalitas. Sedangkan hasil uji Multikolonieritas dapat ditampilkan pada tabel 4 berikut ini :

Tabel 4

Hasil Uji Multikolonieritas

\begin{tabular}{|l|r|r|c|}
\hline \multirow{2}{*}{ Variabel } & \multicolumn{2}{|c|}{ Nilai } & \multirow{2}{*}{ Kesimpulan } \\
\cline { 2 - 3 } & Tolerance & \multicolumn{1}{|c|}{ VIF } & \multirow{2}{*}{ Bebas Multikolonieritas } \\
\hline Religiusitas (R) & 0,805 & 1,243 & Bebon \\
\hline Kesadaran Wajib Pajak (KWP) & 0,921 & 1,086 & Bebas Multikolonieritas \\
\hline Pengetahuan Perpajakan (PP) & 0,867 & 1,154 & Bebas Multikolonieritas \\
\hline
\end{tabular}

Sumber : Diolah Penulis, 2018

Berdasarkan tabel 4 di dapatkan nilai Tolerance dari masing-masing variabel $>0,1$ dan nilai VIF dari masing-masing variabel $<10$, hal ini menunjukkan bahwa model regresi yag digunakan terbebas dari gejala multikolonieritas. Jenis asumsi klasik yang ketiga adalah Uji Heteroskedastisitas. Untuk menguji data yang digunakan homogen atau tidak dengan menggunakan Uji Glejser. 
Berikut ini hasil uji glejser ditampilkan pada tabel 5 :

Tabel 5

Hasil Uji Heteroskedastisitas

\begin{tabular}{|c|c|c|c|c|c|}
\hline \multirow[b]{2}{*}{ Model } & \multicolumn{2}{|c|}{ Unstandardized Coefficients } & \multirow{2}{*}{$\begin{array}{c}\text { Standardized } \\
\text { Coefficients } \\
\text { Beta }\end{array}$} & \multirow[b]{2}{*}{$\mathrm{t}$} & \multirow[b]{2}{*}{ Sig. } \\
\hline & $\mathrm{B}$ & Std. Error & & & \\
\hline $1 \quad$ (Constant) & $-2,842 \mathrm{E}-16$ & 3,901 & & 0,000 & 1,000 \\
\hline $\mathrm{R}$ & 0,000 & 0,155 & 0,000 & 0,000 & 1,000 \\
\hline KWP & 0,000 & 0,120 & 0,000 & 0,000 & 1,000 \\
\hline $\mathrm{PP}$ & 0,000 & 0,113 & 0,000 & 0,000 & 1,000 \\
\hline
\end{tabular}

a. Dependent Variable: ABS_RES

Sumber : Diolah Penulis, 2018

Berdasarkan hasil uji glejser di atas di dapatkan nilai signifikansi > 0,05, hal ini menunjukkan bahwa model regresi terbebas dari kaidah heteroskedastisitas.

3. Uji Hipotesis

a. Uji Signifikansi Koefisien Regresi secara Parsial (Uji t)

Hasil uji t dapat ditampilkan pada tabel 6 berikut ini :

Tabel 6

Hasil Uji Regresi secara Parsial

\begin{tabular}{|l|c|c|c|c|}
\hline \multicolumn{1}{|c|}{ Hipotesis } & $\mathrm{t}$ & Sig. & Keterangan & Kesimpulan \\
\hline $\begin{array}{l}\text { 1. Religiusitas berpengaruh terhadap } \\
\text { kepatuhan wajib pajak }\end{array}$ & 3,580 & 0,001 & $0,001<0,005$ & $\begin{array}{c}\text { Hipotesis } \\
\text { diterima }\end{array}$ \\
\hline $\begin{array}{l}\text { 2. Kesadaran wajib pajak berpengaruh } \\
\text { terhadap kepatuhan wajib pajak }\end{array}$ & 2,480 & 0,015 & $0,015<0,05$ & $\begin{array}{c}\text { Hipotesis } \\
\text { diterima }\end{array}$ \\
\hline $\begin{array}{l}\text { Pengetahuan perpajakan berpengaruh } \\
\text { terhadap kepatuhan wajib pajak }\end{array}$ & 0,495 & 0,622 & $0,622>0,05$ & $\begin{array}{c}\text { Hipotesis } \\
\text { ditolak }\end{array}$ \\
\hline
\end{tabular}

Sumber : Diolah Penulis, 2018

Berdasarkan tabel 6 di atas, di dapatkan hasil uji hipotesis untuk tiga hipotesis. Hipotesis 1 di dapatkan nilai signifikansi sebesar 0,001, dimana nilai signifikansinya $<0,05$. Hal ini menunjukkan bahwa religiusitas berpengaruh terhadap kepatuhan wajib pajak. Untuk hipotesis kedua di dapatkan nilai signifikansi sebesar 0,015, dimana 0,015 $<0,05$ yang menunjukkan bahwa hipotesis diterima. Dengan kata lain kesadaran wajib pajak berpengaruh terhadap kepatuhan wajib pajak. Selanjutnya hipotesis ketiga ditolak dimana nilai signifikansi sebesar 0,622. Nilai signifikansi tersebut lebih besar dari 0,05, yang berarti bahwa pengetahuan perpajakan tidak berpengaruh terhadap kepatuhan wajib pajak. 
b. Uji Signifikansi Koefisien Regresi secara Simultan (Uji f)

Hasil uji regresi secara simultan ditampilkan dalam tabel 7 berikut ini :

Tabel 7

Hasil Uji Regresi Simultan

\begin{tabular}{|c|c|c|c|c|c|c|}
\hline & Model & $\begin{array}{c}\text { Sum of } \\
\text { Squares }\end{array}$ & $d f$ & Mean Square & $F$ & Sig. \\
\hline \multirow[t]{3}{*}{1} & Regression & 317.250 & 3 & 105.750 & 10.167 & $.000^{\circ}$ \\
\hline & Residual & 998.510 & 96 & 10.401 & & \\
\hline & Total & 1315.760 & 99 & & & \\
\hline
\end{tabular}

Sumber : Diolah Penulis, 2018

Berdasarkan uji simultan di atas di dapatkan nilai signifikansi sebesar 0,000. Hal ini menunjukkan bahwa $0,000<0,005$ yang berarti bahwa terdapat pengaruh secara bersama sama antara religiusitas, kesadaran wajib pajak dan pengetahuan perpajakan terhadap kepatuhan wajib pajak.

c. Koefisien Determinasi $\left(R^{2}\right)$

Hasil koefisien determinasi $\left(R^{2}\right)$ dapat ditampilkan pada tabel 8 berikut ini :

Tabel 8

Koefisien Determinasi

\begin{tabular}{|l|r|r|r|r|}
\hline Model & $R$ & $R$ Square & $\begin{array}{c}\text { Adjusted } R \\
\text { Square }\end{array}$ & $\begin{array}{l}\text { Std. Error of } \\
\text { the Estimate }\end{array}$ \\
\hline 1 & $.491^{\mathrm{a}}$ & .241 & .217 & 3.225 \\
\hline
\end{tabular}

Sumber : Diolah Penulis, 2018

Berdasarkan hasil koefisien determinasi di atas di dapatkan nilai $\left(R^{2}\right)$ sebesar 0,241 dan nilai adjusted $\left(R^{2}\right)$ sebesar 0,217 . Hal ini menunjukkan variansi variabel kepatuhan dapat di dipengaruhi oleh variabel religiusitas, kesadaran wajib pajak dan pengetahuan perpajakan sebesar 21,7\%, sedangkan sisanya yaitu sebesar 78,3\% variabel kepatuhan wajib pajak dipengaruhi oleh variabel lain yang tidak di teliti dalam model penelitian ini.

1. Religiusitas Terhadap Kepatuhan Wajib Pajak

Hipotesis pertama menunjukkan bahwa religiusitas berpengaruh terhadap kepatuhan wajib pajak. Wajib pajak orang pribadi di Kabupaten Pati memiliki tingkat religiusitas yang tinggi, dimana wajib pajak yang memiliki tingkat kepercayaan yang tinggi terhadap agamanya akan membentuk perilaku yang etis. Perilaku yang etis ini dapat dilihat dari bagaimana wajib pajak dalam menjalankan kewajiban pajaknya. Wajib pajak yang memegang 
teguh agama nya akan berusaha mematuhi aturan agama yang di anutnya. Semakin tinggi tingkat iman seseorang akan membentuk perilaku yang baik. Perilaku yang baik ini dalam hal pembayaran pajak. Wajib pajak akan merasa bersalah ketika tidak mematuhi peraturan perpajakan. Dengan mematuhi peraturan perpajakan ini, wajib pajak juga mematuhi peraturan agama. Karena dengan membayar pajak ke kas Negara, sama saja wajib pajak membantu dan mendukung perekonomian Negara. Dengan mendukung perekonomian Negara berarti dapat membantu banyak masyarakat di Indonesia.

Hasil penelitian ini sejalan dengan penelitian yang telah dilakukan oleh Utama dan Wahyudi (2016), Benk, et al (2016), Retyowati (2016), Anggraeni (2016), Torgler (2012), Wati (2016) yang nenunjukkan bahwa religiusitas berpengaruh terhadap kepatuhan wajib pajak. Namun hasil penelitian ini tidak mendukung penelitian yang pernah dilakukan oleh Widagsono (2017), Wati (2016), Rahmawaty (2014), Mckerchar, et al. (2013), Raihana dan Ali (2013) yang menunjukkan bahwa religiusitas tidak dapat mempengaruhi kepatuhan wajib pajak.

\section{Kesadaran Wajib Pajak Terhadap Kepatuhan Wajib Pajak}

Hipotesis kedua menunjukkan bahwa kesadaran wajib pajak berpengaruh terhadap kepatuhan wajib pajak. Kesadaran wajib pajak merupakan sikap wajib dalam menjalankan kewajiban perpajakan tanpa dipaksa oleh pihak manapun. Hasil penelitian menunjukkan bahwa tingkat kesadaran yang dimiliki oleh wajib pajak orang pribadi di Kabupaten Pati tinggi. Tingginya kesadaran wajib pajak ini sesuai dengan Theory of Plan Behaviour, dimana teori tersebut mengemukakan bahwa seseorang akan melakukan suatu tindakan berdasarkan motivasi. Motivasi disini adalah kesadaran wajib pajak. Wajib pajak patuh terhadap peraturan perpajakan, di dorong oleh adanya kesadaran yang dimiliki wajib pajak bahwa pajak sangat penting bagi Negara. Wajib pajak yang sadar akan pentingnya pajak bagi kesejahteraan masyarakat Indonesia, akan berusaha membayar pajak tepat waktu. Dengan membayar pajak tepat waktu, kesejahteraan masyarakat Indonesia akan meningkat.

Hal di atas sejalan dengan penelitian yang telah dilakukan oleh Arum (2012), Khasanah (2014), Effendi dan Aris (2016), Suhartini (2012), yang menunjukkan bukti bahwa kesadaran wajib pajak mampu mempengaruhi kepatuhan wajib pajak. Namun penelitian yang telah dilakukan oleh Setyonugroho (2012), Rahman (2013), menunjukkan bukti bahwa kesadaran wajib pajak tidak mampu mempengaruhi kepatuhan wajib pajak. 


\section{Pengetahuan Perpajakan Terhadap Kepatuhan Wajib Pajak}

Hasil pengujian hipotesis ketiga menunjukkan bahwa pengetahuan perpajakan tidak berpengaruh terhadap kepatuhan wajib pajak. Pengetahuan perpajakan yang dimiliki wajib pajak orang pribadi di Kabupaten Pati rendah, sehingga tidak mampu mempengaruhi kepatuhan wajib pajak. Rendahnya pengetahuan perpajakan yang dimiliki oleh wajib pajak inilah yang menyebabkan wajib pajak tidak begitu memahami tentang tata cara yang berkaitan dengan perpajakan. Hal-hal yang tidak dipahami oleh wajib pajak salah satunya adalah bagaimana cara menghitung pajak dengan benar, bagaimana cara membayar pajak, bagaimana cara melaporkan pajak, kapan membayar pajak tepat waktu. Ketidakpahaman tentang perpajakan yang dimiliki oleh wajib pajak inilah yang menyebabkan wajib pajak tidak menjalankan kewajiban perpajakannya. Ketika wajib pajak tidak memahami hak dan kewajiban sebagai wajib pajak dan tidak memahami sanksi-sanksi yang dapat diterima ketika melanggar peraturan perpajakan menyebabkan wajib pajak tidak akan menjalankan kewajiban perpajakannya secara benar. Hal ini lah yang menyebabkan pengetahuan perpajakan tidak dapat berpengaruh terhadap kepatuhan wajib pajak. Hasil penelitian ini tidak mendukung penelitian yang telah dilakukan oleh Widagsono (2017), Rahmawaty (2014), Suhartini (2012), Khasanah (2014) dan Wati (2016).

\section{Kesimpulan}

Kesimpulan yang dapat ditarik dari pembahasan penelitian di atas sebagai berikut :

1. Religiusitas berpengaruh terhadap kepatuhan wajib pajak,

2. Kesadaran wajib pajak berpengaruh terhadap kepatuhan wajib pajak,

3. Pengetahuan perpajakan tidak berpengaruh terhadap kepatuhan wajib pajak.

\section{Daftar Pustaka}

Ancok, D. Suroso, F. 2011. Psikologi Islami : Solusi Islam Atas Problem-Problem Psikologi. Yogyakarta : Pustaka Pelajar.

Anggraeni Lady Ayu. 2016. Pengaruh Kesadaran Wajib Pajak, Lingkungan Wajib Pajak, Sikap Religiusitas Wajib Pajak, Dan Kemanfaatan NPWP Terhadap Kepatuhan Wajib Pajak (Studi Empiris pada Wajib Pajak Orang Pribadi yang Terdaftar di Kantor Pelayanan Pajak Pratama Klaten). Skripsi. Fakultas Ekonomi Dan Bisnis, Jurusan Akuntansi Universitas Muhammadiyah Yogyakarta.

Arum Harjanti Puspa. 2012. Pengaruh Kesadaran Wajib Pajak, Pelayanan Fiskus, Dan Sanksi Pajak Terhadap Kepatuhan Wajib Pajak Orang Pribadi Yang Melakukan Kegiatan 
Usaha dan Pekerjaan Bebas (Studi Di Wilayah KPP Pratama Cilacap). Skripsi. Program Sarjana Fakultas Ekonomi Universitas Diponegoro.

Basri, Yesi Mutia. 2015. Pengaruh Dimensi Budaya Dan Religiusitas Terhadap Kecurangan Pajak. AKUNTABILITAS Vol. VIII, No. 1, April 2015 P-ISSN: 1979-858X Halaman $61-77$

Benk Serkan, Tamer Budak, Bahadır Yuzba, Raihana Mohdali. 2016. The Impact Of Religiosity On Tax Compliance Among Turkish Self-Employed Taxpayers. Religions 2016, 7, 37; Doi:10.3390/Rel7040037.

Capanna Cristina, Paolo Stratta, Alberto Collazzoni and Alessandro Rossi. 2013. Construct and Concurrent Validity of the Italian Version of the Brief Multidimensional Measure of Religiousness/Spirituality. Psychology of Religion and Spirituality, Vol. 5, No.4, 316-324. University of L'Aquila.

Effendi Miftahuddin, Aris Muhammad Abdul. 2016. Analisis Faktor-Faktor Yang Mempengaruhi Kepatuhan Wajib Pajak Dalam Pemenuhan Kewajiban Perpajakannya (Studi Empiris Pada Wajib Pajak Orang Pribadi Yang Terdaftar Di Kantor Pelayanan Pajak Pratama Surakarta). Seminar Nasional dan Call For Paper Program Studi Akuntansi-Feb Ums, 25 Juni 2014 Isbn: 978-602-70429-2-6 Syariah Accounting Paper FEB-UMS.

Fikriningrum, Winda Kurnia. 2012. Faktor-Faktor yang Mempengaruhi Wajib Pajak Orang Pribadi dalam Memenuhi Kewajiban Membayar Pajak (Studi Kasus pada Kantor Pelayanan Pajak Pratama Semarang Candisari). Skripsi. Universitas Riau

Ghozali, Imam. 2011. Aplikasi Analisis Multivariate dengan Program IBM SPSS 21, Edisi 7. Semarang: Badan Penerbit Universitas Diponegoro.

Jotopurnomo, Cindy dan Yenni Mangoting. 2013. "Pengaruh Kesadaran Wajib Pajak, Kualitas Pelayanan Fiskus, Sanksi Perpajakan, Lingkungan Wajib Pajak Berada Terhadap Kepatuhan Wajib Pajak Orang Pribadi di Surabaya". Tax \& Accounting Review, Vol 1, No 1.

Khasanah Septiyani Nur. 2014. Pengaruh Pengetahuan Perpajakan, Modernisasi Sistem Administrasi Perpajakan, Dan Kesadaran Wajib Pajak Terhadap Kepatuhan Wajib Pajak Pada Kantor Wilayah Direktorat Jenderal Pajak Daerah Istimewa Yogyakarta. Skripsi. Fakultas Ekonomi Universitas Negeri Yogyakarta.

Kuncoro, Amin dan Sudarman. 2018. Metodologi Penelitian Manajemen. Penerbit Andi : Yogyakarta

Mckerchar, M., Bloomquist, K., \& Pope, J. 2013. Indicators Of Tax Morale: An Exploratory Study. Ejournal Of Tax Research, 11(1), 5-22.

Rahman, I. S. 2013. Pengaruh Faktor-Faktor Eksternal terhadap tingkat Kepatuhan Membayar Pajak: Studi Empiris terhadap Wajib Pajak Orang Pribadi di Kantor Pelayanan Pajak Pratama Indramayu. Skripsi. UMY. Yogyakarta. 
Raihana Nor, Mohd Ali. 2013. The Influence Of Religiosity On Tax Compliance In Malaysia. Thesis The Degree Of Doctor Of Philosophy Of Curtin University.

Rahmawaty, Stella. 2014. "Pengaruh Pengetahuan Modernisasi Strategi Direktoral Jenderal Pajak, Sanksi Perpajakan dan Religiusitas yang Dipersepsikan Terhadap Kepatuhan Perpajakan". Jurnal Ilmiah Mahasiswa Fakultas Ekonomi dan Bisnis Universitas Brawijaya, Vol 3, No 1.

Retyowati, Fitriana Dikky. 2016. Analisis Faktor-Faktor Yang Mempengaruhi Ketidakpatuhan Wajib Pajak Yang Terdaftar Pada KPP Pratama Sukoharjo. Publikasi Ilmiah Fakultas Ekonomi Dan Bisnis Universitas Muhammadiyah Surakarta.

Suhartini, M. 2012. Faktor-Faktor yang Memengaruhi Kepatuhan Wajib Pajak: Studi Empiris terhadap Wajib Pajak Orang Pribadi di KPP Pratama Daerah Istimewa Yogyakarta. Skripsi. UMY. Yogyakarta.

Sanusi, Anwar. 2017. Metodologi Penelitian Bisnis. Salemba Empat : Jakarta

Setyonugroho, H. 2012. Faktor-Faktor yang Memengaruhi untuk Membayar Pajak pada Wajib Pajak Orang Pribadi di KPP Pratama Surabaya Tegalsari, Artikel Ilmiah, STIE PERBANAS, Surabaya.

Sugiyono. 2010. Statistik untuk Pendidikan. Alfabeta : Bandung

Tahar, Afrizal dan Rachman, Arnain Kartika. 2014. Pengaruh Faktor Internal Dan Faktor Eksternal Terhadap Kepatuhan Wajib Pajak. Jurnal Akuntansi \& Investasi Vol. 15 No.1

Tania T. S.,, 2011, Pengaruh Keadilan Sistem Perpajakan dan Religiusitas terhadap Niat dan Ketidakpatuhan Wajib Pajak (Studi pada Wajib Pajak Orang Pribadi yang Terdaftar di Kantor Pelayanan Pajak Pratama Tampan, Kota Pekanbaru). Skripsi. Universitas Riau.

Torgler, B. 2012. Attitudes Toward Paying Taxes In The Usa: An Empirical Analysis The Ethics Of Tax Evasion. The Ethics Of Tax Evasion: Perspectives In Theory And Practice (Pp. 269-283). New York:Springer.

Utama Andhika, Dudi Wahyudi. 2016. Pengaruh Religiusitas Terhadap Perilaku Kepatuhan Wajib Pajak Orang Pribadi Di Provinsi DKI Jakarta. Jurnal Lingkar Widyaiswara Edisi 3 No. 2, Apr - Jun 2016, P.01-13 ISSN : 2355-4118

Utami, Sri Rizki, Andi dan Ayu Noorida Soerono., 2012. Pengaruh FaktorFaktor Eksternal Terhadap Tingkat Kepatuhan Wajib Pajak di Lingkungan Kantor Pelayanan Pajak Pratama Serang. Jurnal Universitas Sultan Ageng Tirtayasa.

Wati, Reny Eka. 2016. Pengaruh Pengetahuan Modernisasi Strategi Direktorat Jenderal Pajak, Sanksi Perpajakan, Kualitas Pelayanan Fiskus dan Religiusitas yang Dipersepsikan Terhadap Kepatuhan Perpajakan. Naskah Publikasi, Fakultas Ekonomi dan Bisnis, Surakarta: Universitas Muhammadiyah Surakarta. 
Widagsono Seto. 2017. Pengaruh Pengetahuan Perpajakan, Sanksi, dan Religiusitas terhadap Kepatuhan Wajib Pajak (Studi Kasus pada KPP Pratama Kepanjen). Skripsi. Jurusan Akuntansi Fakultas Ekonomi Universitas Islam Negeri Maulana Malik Ibrahim Malang.

Widayati dan Nurlis. 2010. "Faktor-faktor yang Mempengaruhi Kemauan untuk Membayar Pajak WAjib Pajak Orang Pribadi yang Melakukan Pekerjaan Bebas (Studi Kasus pada KPP Pratama Gambir Tiga)". Simposium Nasional Akuntansi XIII, Purwokerto. 